\title{
Role Ambiguity, Role Conflict, Auditor Competence on Audit Quality: The Mediating Effects of Auditing Planning and Independence
}

\author{
Jamaluddin*, Masruddin, Indra Basir, Rahma Masdar, Lucyani Meldawati \\ Department of Accounting, Faculty of Economics and Business, Tadulako University, Palu, Indonesia
}

Received September 24, 2021; Revised November 18, 2021; Accepted November 29, 2021

\section{Cite This Paper in the following Citation Styles}

(a): [1] Jamaluddin, Masruddin, Indra Basir, Rahma Masdar, Lucyani Meldawati, "Role Ambiguity, Role Conflict, Auditor Competence on Audit Quality: The Mediating Effects of Auditing Planning and Independence," Universal Journal of Accounting and Finance, Vol. 9, No. 6, pp. 1551-1557, 2020. DOI: 10.13189/ujaf.2021.090632.

(b): Jamaluddin, Masruddin, Indra Basir, Rahma Masdar, Lucyani Meldawati (2021). Role Ambiguity, Role Conflict, Auditor Competence on Audit Quality: The Mediating Effects of Auditing Planning and Independence. Universal Journal of Accounting and Finance, 9(6), 1551-1557. DOI: 10.13189/ujaf.2021.090632.

Copyright $\mathrm{C} 2021$ by authors, all rights reserved. Authors agree that this article remains permanently open access under the terms of the Creative Commons Attribution License 4.0 International License

\begin{abstract}
The purpose of this study was to determine and analyze the effect of role ambiguity, role conflict and auditor competence on auditor independence and internal audit quality as well as the effect of auditor independence and audit planning on internal audit quality. It is also to empirically analyze the mediating effects of auditor independence and audit planning in the relationship between independent variables to dependent variable of internal audit quality. The population of this research is auditor inspectorate in Central Sulawesi Province. Sampling used purposive sampling technique with a total of 202 samples. The data were analyzed using the Structural Equation Model (SEM) technique. The results showed that role ambiguity and role conflict had a significant negative effect on auditor independence, but did not significantly affect the quality of internal audit. Auditor competence has a positive effect on auditor independence and internal audit quality. The findings also pointed out that auditor independence and audit planning have a significant positive effect on internal audit quality. Statistical testing of mediating variables showed that auditor independence mediates the relationship between role ambiguity and role conflict and the quality of internal audit. Likewise, mediating variables of auditor independence and audit planning have empirically proven to strengthen the effect of auditor competence on the quality of internal audit.
\end{abstract}

Keywords Audit Quality, Public Sector Audit, Internal Audit, Role Ambiguity, Role Conflict, Auditor Competence

\section{Introduction}

Internal auditors also play a role in the implementation of Good Corporate Governance (GCG) both for company and government. It can assist management in improving company performance, especially from the control aspect. It is also very important in increasing compliance in applying the principles of good governance. An effective internal audit process is critical to the success of good governance. On other hand, good governance is very important to achieve sustainable growth and development in an organization or country [1]. Guruswamy [2] states that the internal audit function can be viewed as the main gate to adequate corporate governance and financial reporting.

The audit must be carried out by an auditor who always uses his professional skills carefully and thoroughly. This must not only be done by an external auditor or an independent auditor who audits financial statements, but also must be done by an internal auditor. Internal auditors conduct independent assessments within an organization to 
test and evaluate the organization's internal control system and assess whether policies, regulations and work guidelines within the organization have been met by members of the organization. Therefore, internal auditors are expected to conduct quality audits in order to detect and prevent fraud or fraud and provide useful recommendations in the work environment.

The auditor ability to report important matters by independence level. Independence is one of the determinants of audit quality. Auditors must have an independent mental attitude. Auditor competence is related to their independence in collecting and providing evidence during the audit process $[3,4]$. Specifically in Indonesia, the Indonesian Institute of Certified Public Accountants/IAPI [5] article 220 PSA No. 4 Paragraph 02 requires auditors to be independent, meaning that they are not easily influenced, and genuinely carry out work in the public interest. Therefore, they are not justified in taking partisan interests. In this case, the auditor's technical expertise relates to the impartiality aspect in order to maintain freedom of opinion regarding the audit results. This study aims to analyze the effect of role ambiguity, role conflict and auditor competence on auditor independence and internal audit quality. It also comprehensively examines the mediating effects of auditor independence and audit planning in the relationship between role ambiguity, role conflict and auditor competence on internal audit quality.

\section{Literature Review and Hypothesis Development}

Luthans (2001) describes role ambiguity as a condition of being unclear about the individual tasks of the job. This includes unclear job descriptions, instructions, and lack of experience which ultimately contribute to role ambiguity. Overall, low ambiguity of the auditor's role indicate unclear guidelines, duties, responsibilities, standards and effective time allocation will increase auditor independence. Role ambiguity has a negative effect on independent commitment Ahmad \& Taylor [6] who conducts research on internal auditors in Malaysia. Page \& Spira [7] states that ambiguity undermines the preservation of professional power and provides space for interested groups to maneuver. Abdullah et al. [8], conducted a study at the Semarang City inspectorate. The results show that role ambiguity has a significant negative effect on commitment to independence.

The results of research conducted by Gahlan \& Singh [9] found role ambiguity as a significant determinant of job performance. This means that individuals who are not clear about their main role until the lack of information needed for successful performance of that role will not result in their performance declining. The low level of auditor role conflict through the reduction of inter-role conflict, intra-role conflict, and personal role conflict resulted in increased auditor independence. Viator [10] found that role ambiguity and perceived environmental uncertainty were negatively correlated with job performance. Fisher [11] found that role ambiguity has a significant negative effect on job performance and auditor job satisfaction. Iqbal et al. [12] show that role ambiguity has no significant effect on auditor performance.

H1: Role ambiguity has a negative effect on auditor independence.

H2: Role ambiguity has a negative effect on the quality of internal audit.

Role conflict refers to the emergence of conflicting roles that must be carried out by individuals as members of an organization [13]. This results in individuals experiencing role conflict unable to make the right decisions about how these roles will be carried out properly. Inspectorate apparatus in carrying out their duties in the government environment, will relate to other sections or individuals. This relationship is likely to result in differences that lead to conflict. Ahmad \& Taylor [6], Abdullah et al. [8], role conflict has a significant negative effect on commitment to independence. Research Reynolds [14] concludes that the conflict that occurs because of the audit role and the consulting role of the internal auditor is the subject of conflict. Fisher [11] show that role conflict has a negative effect on job performance and auditor job satisfaction and that role conflict has a significant effect on auditor performance. Role conflict has a negative effect on work performance $[10,15]$. Koustelios et al. [16], role conflict is a significant determinant of job satisfaction. Jamaluddin \& Syarifuddin [17] found that role conflict affects auditor independence.

H3: Role conflict has a negative effect on auditor independence.

H4: Role conflict has a negative effect on the quality of internal audit.

Accounting competencies and expertise are introduced in audit professionals [18]. Auditors must understand accounting standards, accounting systems, accounting rules, and accounting information technology for planning in audit field work. The audit plan helps the auditor to audit the financial statements including considering audit materiality, audit issues, and audit systematics. Shoommuangpak \& Ussahawanitchakit [19] found that accounting competence can assist auditors in auditing strategies to focus on risk assessment, internal control monitoring, fraud detection, negotiation tactics, and advisory expertise. They define accounting competence as professional knowledge with standard principles, internal control systems, regulations, and information technology.

H5: Auditor competence has a positive effect on auditor independence

H6: Auditor competence has a positive effect on audit planning

H7: Auditor competence has a positive effect on the quality of internal audit 
The function of the internal auditor is to carry out an internal audit function which is an independent assessment function within an organization to test and evaluate the organization's activities [20]. Thomas C. Wooten [21] provides a model of audit quality, that audit quality can be measured by two main factors, namely the ability to detect errors that occur in an organization and the ability to report errors that occur. The ability to report errors is strongly influenced by the level of auditor independence. Ideally, internal auditors should be free to report on their audit matters and their reporting activities should not be influenced by anyone [20]. The International Standards for the Professional Practice of Internal Auditing have identified the independence of internal auditors as the most important criterion for the effectiveness of the internal audit function [22].

H8: Auditor independence has a positive effect on the quality of internal audit

Shoommuangpak \& Ussahawanitchakit [19] define audit efficiency as leading to the success of audit objectives by gathering sufficient and appropriate audit evidence to obtain a fair opinion regarding the compliance of financial statements with generally accepted accounting principles. Time and staff constraints require the auditor to pay attention to the scope of the audit. The scope of the audit is defined as that additional effort beyond the usual level given the inherent risk associated with the account [23 - 25]. Chanruang \& Ussahawanitchakit [26] found that audit planning competence is positively related to the quality of audit reports. Laohamethanee \& Ussahawanitchakit [27] research results show that audit planning (tracing client background information, determining materiality level, risk assessment, preliminary analytical review, and understanding internal control structure) has a positive effect on audit quality.

H9: Audit planning has a positive effect on internal audit quality

According to Arens et al. [3] stated that the competence of the people who carry out the audit will be of no value if they are not independent in collecting and evaluating evidence.

Aghghaleh et al. [28], Alleyne et al. [29], and Mukhtaruddin [30] revealed that auditor independence is likely able to strengthen the effect of role ambiguity on the quality of internal audit. Moreover, previous studies [31, 32] have found the mediating effect of auditor independence in the relationship between role conflicts on internal audit quality.

H10: Auditor independence mediates the relationship between role ambiguity on the quality of internal audit.

H11: Auditor independence mediates the relationship between role conflict and the quality of internal audit.

Chanruang \& Ussahawanitchakit [26] stated that accounting competence is positively related to the efficiency of audit methods, resource allocation, audit scope setting, but negatively related to the use of audit knowledge. Audit experience is positively related to the efficiency of audit methods, resource allocation, audit scope setting, and use of audit knowledge. Al Matarneh [33] conducted a study with the results showing the competence, objectivity and performance of internal auditors as important factors affecting the quality of internal audit. Mansouri et al. [34] stated that the competence of AICPA members has an effect on fraud detection.

H12: Auditor independence mediates the relationship between auditor competence and the quality of internal audit

H13: Audit planning mediates the relationship between auditor competence and the quality of internal audit

\section{Methods}

The research aims to identify and analyze the effect of role ambiguity, role conflict and auditor competence on auditor independence and internal audit quality. It is also to empirically examine the mediating effects of auditor independence and audit planning in the relationship between role ambiguity, role conflict and auditor competence and the quality of internal audit. The population of this research is auditor inspectorate in Central Sulawesi Province. Sampling used purposive sampling technique with a total of 202 samples. The data were analyzed using the Structural Equation Model (SEM) technique.

\section{Results}

Direct effect is the effect that is directly measured from one variable to another. There are nine direct effects tested in this study which can be seen in Table 1 . 
Role Ambiguity, Role Conflict, Auditor Competence on Audit Quality:

The Mediating Effects of Auditing Planning and Independence

Table 1. Results of Testing the Direct Effect on the Structural Model

\begin{tabular}{|c|c|c|c|}
\hline Direct Influence & Standardized Coefficient & p-value & Conclusion \\
\hline Role ambiguity $\rightarrow$ Auditor independence & -0.275 & 0.013 & Significant \\
\hline Role ambiguity $\rightarrow$ Internal audit quality & -0.103 & 0.226 & Not significant \\
\hline Role conflict $\rightarrow$ Auditor independence & -0.231 & 0.031 & Significant \\
\hline Role conflict $\rightarrow$ Internal audit quality & -0.027 & 0.751 & Not significant \\
\hline Auditor competence $\rightarrow$ Auditor independence & 0.456 & 0.001 & Significant \\
\hline Auditor competence $\rightarrow$ Audit planning & 0.520 & 0.001 & Significant \\
\hline Auditor competence $\rightarrow$ Internal audit quality & 0.352 & 0.012 & Significant \\
\hline Auditor independence $\rightarrow$ Internal audit quality & 0.418 & 0.006 & Significant \\
\hline Audit Planning $\rightarrow$ Internal audit quality & 0.358 & 0.001 & Significant \\
\hline
\end{tabular}

Graphically, the results of structural testing of the model are presented in full in Figure 1. Straight lines in the figure represent significant paths, and dotted lines represent non-significant paths.

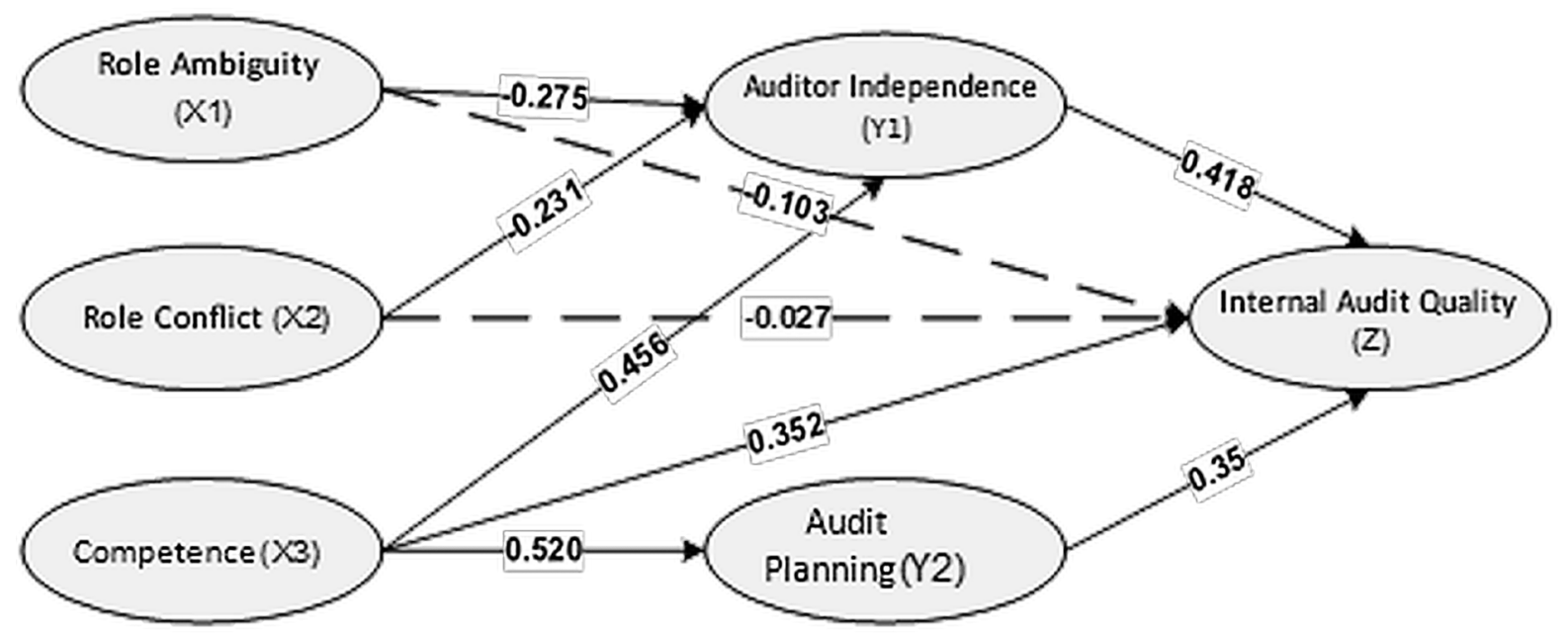

Figure 1. Structural Results of the Direct Effect Testing Model

Moreover, indirect influence is the effect that is measured indirectly on one variable to another through an intervening variable. The coefficient of indirect effect is obtained from the product of the two direct effects. If the two coefficients of direct influence are significant, then the coefficient of indirect influence is also significant. However, if one or both of the direct influence coefficients are not significant, then the indirect effect coefficients are not significant. In this study there are four indirect effects that are tested as shown in Table 2.

Table 2. Indirect Effect in Structural Model

\begin{tabular}{|c|c|c|c|c|c|}
\hline Relationship & Direct Effect & Indirect Effect & Total effect & p-value & Conclusion \\
\hline Role ambiguity $\rightarrow$ Auditor independence $\rightarrow$ audit quality & -0.103 & -0.115 & $-0.215^{* *}$ & $<0.05$ & Significant \\
\hline Role conflict $\rightarrow$ Auditor independence $\rightarrow$ audit quality & -0.027 & $-0.097^{* *}$ & $-0.124^{* *}$ & $<0.05$ & Significant \\
\hline Auditor competence $\rightarrow$ Auditor independence $\rightarrow$ audit quality & 0.352 & $0.191^{* *}$ & $0.543^{* *}$ & $<0.05$ & Significant \\
\hline Auditor competence $\rightarrow$ Audit Planning $\rightarrow$ Internal audit quality & 0.352 & $0.186^{* *}$ & $0.538^{* *}$ & & Significant \\
\hline
\end{tabular}


The statistical testing showed that empirically, role ambiguity has a significant negative effect on auditor independence, while it has no significant effect on the quality of internal audit. Moreover, role conflict has a significant negative effect on auditor independence, and has no significant effect on the quality of internal audit.

In terms of auditor competence, it has a significant positive effect on auditor independence and also has a significant positive effect on audit planning. Auditor competence is also empirically having a significant positive effect on the quality of internal audit and a significant positive effect on the quality of internal audit. In addition, the results showed that audit planning has a significant positive effect on the quality of internal audit. This implies that audit planning is a factor that plays an important role in determining the high and low quality of internal audit. The higher the value of audit planning, the higher the value of internal audit quality will be. Conversely, if the value of audit planning is getting lower, then the quality of internal audit is also getting lower. Audit planning which consists of the dimensions of efficiency of audit methods, allocation of audit resources, audit scope, and use of audit knowledge can improve the quality of internal audit Fuad [35].

This study is in line with the results or previous studies. Al Matarneh [33] found that the competence, objectivity, and performance of internal auditors as important factors on the quality of internal audit. Mansouri et al. [34] states that the competence of AICPA members has an effect on fraud detection. Suyono [36] found that independence, experience, and responsibility simultaneously affect audit quality. Auditor competence has a significant effect on auditor performance. Masdar et al. [37] conducted research on the Gorontalo City inspectorate apparatus. The results indicate that the competence of auditors has a significant effect on audit quality. Jamaludin et al. [38] conducted a study by finding auditor competence to have a positive effect on auditor independence.

Robkob et al. [39] conducted a study with a population of tax certification auditors in Thailand. The results indicate that auditor independence has a significant effect on audit quality. Baotham \& Ussahawanitchakit [40] conducting a study with a population of auditors in Thailand showed that audit independence had a positive effect on audit quality and credibility. Suyono [34] conducted research on auditors of Public Accounting Firms in Central Java and Yogyakarta Provinces. The results found that independence had an effect on audit quality [37].

In examining the role of mediating variables, the findings showed that auditor independence mediates the effect of role ambiguity on internal audit quality. This means that role ambiguity has an influence on the quality of internal audit only as mediated by auditor independence. The results are in line with Mukhtaruddin et al. [30] demonstrating the effect of auditor independence in the relationship between role ambiguity and the quality of internal audit. The results are also consistent with Tang \& Chang [41], Keong [42], and Smith \& Emerson [43].

The results of this study indicate that the auditor independence mediates the effect of role conflict on internal audit quality. It means that the lower the value of role conflict will encourage increased auditor independence, so that it will improve the quality of internal audit. The results are in line with previous studies highlighting the mediating effect of auditor independence in the relationship between role conflict on internal audit quality $[31,32]$.

The findings revealed that auditor independence mediates the effect of auditor competence on internal audit quality. This means that the effect of auditor competence on the quality of the internal audit is strengthened by mediating effect of auditor independence. This indicates that an increase in auditor competence will be an increase in auditor independence, and will further improve the quality of internal audit. The higher the value of the auditor's competence, the higher the value of auditor independence will be and further encourage the improvement of the quality of internal audit. The results are consistent with the results revealed by previous research demonstrating the mediating effect of auditor independence between auditor competences on internal audit quality [44], [45], [34], [46]. Overall, this study highlighted that knowledge, expertise, and increased expertise of auditor is more likely able to improve the quality of internal audit with the increased position of auditor independence. In term of the positive indirect effect of auditor competence on the quality of internal audit, it pointed out the important role of audit planning.

\section{Conclusions}

The results showed that role ambiguity and role conflict had a significant negative effect on auditor independence, but did not significantly affect the quality of internal audit. Auditor competence has a positive effect on auditor independence and internal audit quality. The findings also pointed out that auditor independence and audit planning have a significant positive effect on internal audit quality. Statistical testing of mediating variables showed that auditor independence mediates the relationship between role ambiguity and role conflict and the quality of internal audit. Likewise, mediating variables of auditor independence and audit planning have empirically proven to strengthen the effect of auditor competence on the quality of internal audit.

Statistical findings revealed that the auditor independence mediates the effect of role conflict on internal audit quality. It means that the lower the value of role conflict will encourage increased auditor independence, so that it will improve the quality of internal audit. The findings revealed that auditor independence 
mediates the effect of auditor competence on internal audit quality. This means that the effect of auditor competence on the quality of the internal audit is strengthened by mediating effect of auditor independence. This indicates that an increase in auditor competence will be an increase in auditor independence, and will further improve the quality of internal audit. The higher the value of the auditor's competence, the higher the value of auditor independence will be and further encourage the improvement of the quality of internal audit.

\section{REFERENCES}

[1] Chev Chevers, Jacqueline Ella, Delroy Chevers, Trevor Munroe, "The Internal Audit Process and Good Governance: Toward a Research Model," Academy of Business Research, vol. 1, pp. 48-58, 2013.

[2] Guruswamy D., "Role of Internal Auditing to Promote Good Corporate Governance in the Public Sector," Excel International Journal of Multidisciplinary Management Studies, vol. 2, no. 1, 2012.

[3] Alvin A. Arens, Randal J. Elder, Mark S. Beasle, "Auditing dan Jasa Assurance Pendekatan Terintegrasi," Jakarta: Erlangga, 2008.

[4] Muhammad Fakhimuddin, Uswatun Khasanah, Rini Trimiyati, "Database Management System in Accounting: Assessing the Role of Internet Service Communication of Accounting System Information," Research Horizon, vol. 1, no. 3, pp. 100-105, 2021.

[5] Institut Akuntan Publik Indonesia (IAPI), "Standar Profesional Akuntan Publik," Jakarta: Salemba Empat, 2011.

[6] Ahmad Zaini, Dennis Taylor, "Commitment to Independence by Internal Auditors: The Effects of Role Ambiguity and Role Conflict," Managerial Auditing Journal, vol. 24, no. 9, pp. 899-925, 2009.

[7] Mike Page, L. Spira, "Ethics, Independence and the Conservation of Ambiguity," Business Ethics: A European Review, vol. 14, no. 3, pp. 301-316, 2005.

[8] Muhammad Ikbal Abdullah, Andi Chairil Furqan, Nina Yusnita Yamin, Fahri Eka Oktora, "Incentive Function of Audit Opinion for the Increase of Regional Operational Expenditure and Own-Source Revenues through Sensitivity Analysis in Indonesia." Research in World Economy, vol. 11, no. 1, pp. 20-27, 2020.

[9] Vandana Singh Gahlan, Khujan Singh, "The Effect of Role Overload and Role Ambiguity on Job Performance of IT Professionals in India," IUP Journal of Management Research, vol. 13, no. 3, 2014.

[10] Ralph E. Viator, "The Association of Formal and Informal Public Accounting Mentoring with Role Stress and Related Job Outcomes," Accounting, Organizations and Society, vol. 26, no. 1, pp. 73-93, 2001.

[11] Richard T. Fisher, "Role Stress, the Type A Behavior Pattern, and External Auditor Job Satisfaction and Performance," Behavioral Research in Accounting, vol. 13, no. 1, pp. 143-170, 2001.

[12] Muhammad Iqbal, Andi Chairil Furqan, Abdul Kahar, Sudirman Sudirman, Muliati Muliati, "Majority Shareholder on the Composition of Public Ownership and Tax Avoidance Practices in Public Companies," Academic Journal of Interdisciplinary Studies, vol. 9, no. 2, pp. 109-109, 2020.

[13] Chi Mo Koo, Ho Seog Sim, "On the Role Conflict of Auditors in Korea," Accounting, Auditing \& Accountability Journal, vol. 12, no. 2, pp. 206-219, 1999.

[14] Mary Ann Reynolds, "Professionalism, Ethical Codes and the Internal Auditor: A Moral Argument," Journal of Business Ethics, vol. 24, no. 2, pp. 115-124, 2000.

[15] Fadli Moh Saleh, Andi Chairil Furqan, Amy Fontanella, Eko Prasetyo, "Effects of privatization and corporate governance on accounting conservatism in state - owned enterprises," Journal of Public Affairs, vol. 21, no. 3, pp. e2671, 2021.

[16] Athanasios Koustelios, Nicholas Theodorakis, Dimitris Goulimaris, "Role Ambiguity, Role Conflict and Job Satisfaction among Physical Education Teachers in Greece," International Journal of Educational Management, vol. 18, no. 2 , pp. 87-92, 2004.

[17] Jamaluddin Jamaluddin, Syarifuddin Syarifuddin, "Ambiguitas dan Konflik Peran Serta Independensi Sebagai Determinan Kualitas Audit Internal," Jurnal Akuntansi Multiparadigma, vol. 5, no. 3, pp. 421-431, 2015.

[18] Sue Malthus, Carolyn Fowler, "Generation Y perceptions," Chartered Accountants Journal, vol. 88, no. 1, pp. 20-22, 2009.

[19] Pornitp Shoommuangpak, P. Ussahawanitchakit, "Audit Strategy of CPAs in Thailand: How does it affect audit effectiveness and Stakeholder acceptance," International Journal of Business Strategy, vol. 9, no. 2, pp. 136-157, 2009.

[20] Lawrence B. Sawyer, Mortimer A. Dittenhofer, James H. Scheiner, "Sawyer's Internal Auditing. Maitland Avenue, Altamonte Springs. Florida: Internal Auditing Sawyer, 2003.

[21] Thomas C. Wooten, "Research About Audit Quality," The CPA Journal, vol. 73, no. 1, pp. 48, 2003.

[22] Institute of Internal Auditors (IIA), "International Standards for the Professional Practice of Internal Auditing," Institute of Internal Auditors South Africa, 2011.

[23] Simon Ed Baron-Cohen, Helen Ed Tager-Flusberg, Donald J. Cohen, "Understanding other minds: Perspectives from Developmental Cognitive Neuroscience," Oxford University Press, 2000.

[24] Dewi Purnamasari, Ayu Almira, Nadia Della Savira, "The Accounting for Inventory from a Commercial Point of View," Research Horizon, vol. 1, no. 2, pp. 81-85, 2021.

[25] Muhammad Mansyur, "Marketing Opportunities for Bank Syariah Mandiri e-Banking Services as a Payment Method," Research Horizon, vol. 1, no. 2, pp. 71-80, 2021. 
[26] Sakchai Chanruang, Phapruke Ussahawanitchakit, "Audit Sustainability of CPAs in Thailand: Effects of Audit Planning Competency and Audit Report Quality," International Journal of Business Research, vol. 11, no. 6, pp. 57-82, 2011.

[27] Worawit Laohamethanee, Phapruke Ussahawanitchakit, "Audit Professional Skepticism: An Empirical Investigation of Certified Public Accountants (CPAs) in Thailand," Journal of International Management Studies, vol. 12, no. 4, 2012.

[28] Shabnam Fazli Aghghaleh, Zakiah Muhammaddun Mohamed, Azlina Ahmad, "The Effects of Personal and Organizational Factors on Role Ambiguity amongst Internal Auditors," International Journal of Auditing, vol. 2, no. 18, pp. 105-114, 2014.

[29] Philmore Alvin Alleyne, Dwayne Devonish, Peter Alleyne, "Perceptions of auditor independence in Barbados," Managerial Auditing Journal, vol. 21, no. 6, pp. 621-635, 2006.

[30] Mukhtaruddin Mukhtaruddin, Luk Luk Fuadah, Meilin Dina Saputri, "Independencies as Intervening Variable in Role Conflict and Role Ambiguity on Internal Audit Quality," Indonesian Journal of Contemporary Accounting Research, vol. 1, no. 1, pp. 57-68, 2019

[31] Agil Novriansa, Bambang Riyanto, "Role conflict and role ambiguity on local government internal auditors: The determinant and impacts," Journal of Indonesian Economy and Business, vol. 31, no. 1, pp. 63-80, 2016.

[32] Marion Hutchinson, Mazlina Zain, "Internal audit quality, audit committee independence, growth opportunities and firm performance," Corporate Ownership \& Control, vol. 7, no. 2, pp. 50-65, 2009.

[33] Ghassan F. Al Matarneh, "Factors Determining the Internal Audit Quality in Banks: Empirical Evidence from Jordan," International Research Journal of Finance and Economics, vol. 73, no. 9, pp. 99-108, 2011.

[34] Ali Mansouri, Reza Pirayesh, Mahdi Salehi, "Audit Competence and Audit Quality: Case in Emerging Economy," International Journal of Business and Management, vol. 4, no. 2, pp. 17-25, 2009.

[35] Fuad, Zulaikha, Agung Juliarto, "Linking Institutional Environment to the IFRS and Accounting Quality: A Proposed Framework," Universal Journal of Accounting and Finance, vol. 9, no. 3, pp. 347-351, 2021. DOI: 10.13189/ujaf.2021.090308

[36] Eko Suyono, “The Effects of Independence, Experience, and
Accountability to the Audit Quality," In Asia-Pacific Business Research Conference, February, pp. 13-14, 2012.

[37] Masdar, R., Furqan, A.C., Masruddin, M., Meldawaty, L. The role of transparency and professional assistance in regional financial management in the Indonesian regional governments Journal of Public Affairs, 2021, 21(3), e2666.

[38] Jamaludin, Muh. Ali, Mediaty, Syarifuddin, "Effects of Independence Mediation on the Influence of Role Ambiguity, Role Conflict and Auditors 'Competence Towards Internal Audit Quality," Journal of Research in Business and Management, vol. 2, no. 10, pp. 139-145, 2014.

[39] Phaiboon Robkob, Krittaya Sangboon, Teeraporn Leemanonwarachai, "The Influence of audit Independence, Audit Professionalism, and Audit Quality on Audit Value Creation: An Empirical Study of Tax Auditors in Thailand," Review Of Business Research, vol. 12, no. 1, pp. 54-69, 2012.

[40] Sumintorn Baotham, Phapruke Ussahawanitchakit, "Audit Independence, Quality, and Credibility: Effects on Reputation and Sustainable Success of CPAs in Thailand," International Journal of Business Research, vol. 9, no. 1, pp. $1-25,2009$.

[41] Yung-Tai Tang, Chen-Hua Chang, "Impact of role ambiguity and role conflict on employee creativity," African Journal of Business Management, vol. 4, no. 6, pp. 869-881, 2010.

[42] Ooi Keong, "Determinants of Intentions to Engage in Sustainability Accounting \& Reporting (SAR) and Moderating Role of Internal Audit Function: The Perspective of Accountants," Arthatama, vol. 4, no. 1, pp. 33-43, 2020.

[43] Kenneth J. Smith, David J. Emerson, "An analysis of the relation between resilience and reduced audit quality within the role stress paradigm," Advances in accounting, vol. 37, pp. 1-14, 2017.

[44] Lawrence J. Abbott, Brian Daugherty, Susan Parker, Gary F. Peters, "Internal audit quality and financial reporting quality: The joint importance of independence and competence," Journal of Accounting Research, vol. 54, no. 1, pp. 3-40, 2016.

[45] Muhammad Reza, Syed Ullah,'Financial Reporting Quality of the Manufacturing Firms Listed in Indonesian Stock Exchange," Arthatama, vol. 3, no. 1, pp. 37-54, 2019.

[46] S. Zahmatkesh, J. Rezazadeh, "The effect of auditor features on audit quality,” Tékhne, vol. 15, no. 2, pp. 79-87, 2017. 